\title{
Climate change: causes, effects and the need for science education for sustainable development
}

\author{
Hyginus A. Nwona \\ Department of Integrated Science, Federal College of Education, \\ Okene, Kogi State, Nigeria
}

\begin{abstract}
The world we live in has witnessed some drastic environmental imb ance is recent 0 . These

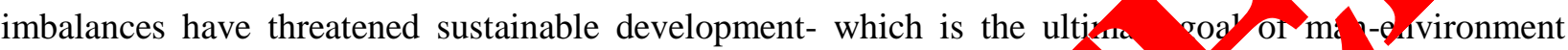
relationship. This paper reviews the causes and effects of climate ch 8 on and $b$, environment with a view to using science education to solve the problems posed climate co Literature shows that climate change results mainly from human activities such as ap forestatio ror agricultural and industrial purposes, carbon dioxide emission from fossil fu rning, bon dioxide emission from burning gasoline for transportation, usage of chemical fertil cers on cropland $\mathbb{A}$ methane emission from animals, agriculture and arctic sea beds. The consequer es of these activit.es include global warming, ozone layer depletion, greenhouse effect, rising sea leve and acid rair It is recommended here that the whole educational process be re-packaged to emphasize ience eduction as a panacea for sustainable development. The argument here is that the educational in the best media for the inculcation of proper morals and values. It is also recomm that teacner education programmes should allocate more funds to research in, and teaching of science in sy
\end{abstract}

Keywords: climate change; science; s educat n; global warming; sustainable development

\section{INTRODUCTIO}

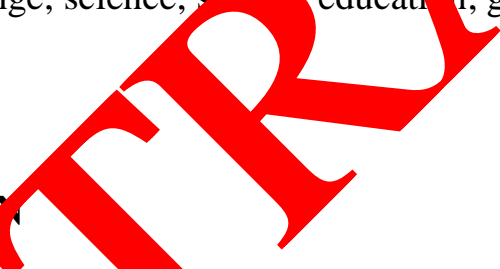

Towards the turn of this ary various governments and researchers became perturbed with regard the ex ctations of the new millennium. This gave rise to formulation of many development. a inten ed to guide nations in channelling their efforts and resources approp $\quad$ y to th ar a d / or goals conceived as critical for the survival of the human race in the ew $\mathrm{n}$ ennium of the results of such efforts gave birth to the formulation of the milh iur davelon ment goals (MDGs) in September 2000, made up of eight goals, eighteen targets rd forty-eight measurable, time-bound indicators aimed at eradicating poverty, hunger, ase, illiteracy, environmental devastation and discrimination against women. These deveopment efforts no doubt are to cater for the well-being of the of the present as well as the future generations, having in mind the desire to leave our world better or at least not worse than we met it. It is obvious then, that science and its applications must play a vital role in this regard. Although science and its applications strive to satisfy human needs, they also take their toll as many activities carried out in the process of development turn out to endanger our environment and as such render it unsustainable.

Many undeveloped and developing nations like Nigeria conceive rapid industrialization as the key driver of sustainable development. Hence, industries are sited haphazardly and 
often without proper assessment of their inherent effects on our environment. Some of the developed nations tactically relocate their manufacturing and industrial activities to the poor developing countries with the intent to 'develop the undeveloped' countries. This action, rather than address the growing anthropogenic pollution, merely changes the jurisdiction of the pollution created from the 'rich' to the 'poor' world. The resultant effect of such activities is an alarming increase in global climate change occasioned by global warming, ozone layer depletion, greenhouse effects, rising sea water level, improper monsoon and acid rain (all of which threaten man and his environment). It becomes very important, therefore, that the masses, especially people in the developing nations be proper education about our natural environment as well as how we can protect and preserve it for the future generat on. Sa education must of necessity come into play if we wish to achieve any rem able level environmental sustainability.

Educational institutions are the most appropriate places where m aningful c an an be made with the younger generation of pupils, engineers and scier ts. T) are best media for the transmission of worthwhile norms and values to the och ge ration to generation, especially on issues that have to do with changing th peoples indse on crucial issues as climate change. On this premise, therefore, science ca tion is pr sted here as a panacea for climate change. This paper shall focus on clin te ch. its causes and effects and how science education can address it in order to ach crosustainat development.

\section{WHAT IS CLIMATE CHANGE?}

The Oxford Dictionary (online versio ches change as the change earth's weather, including changes in tempe tur , patterns and rainfall, especially the increase in the temperature of the-earth's a nosphere that is caused by the increase of particular gases, especially carbo a diu de. Alth ugh this definition places more emphasis on carbon dioxide, other gases as e chloro uorocarbons (CFC's), ozone $\left(\mathrm{O}_{3}\right)$, methane $\left(\mathrm{CH}_{4}\right)$, water vapour, etc a in s chares to global warming. Climate change is a long-term change in the atistical $\mathrm{a}_{\mathrm{H}}$ bution of weather patterns over a long period of time. It may be limited to a pee region, o may occur across continents.

Until the pa ntury, ural factors caused atmospheric $\mathrm{CO}_{2}$ concentrations to vary within a range of 180 to 300 its per million by volume (ppmv). A report by the U.S. National Re rch $C$ acil (NRC, 2010) shows that the figure had risen to $390 \mathrm{ppmv}$ in the last century. arly, tl National Oceanic and Atmospheric Administration, NOAA's Annual enhou. Gas index (2010) also shows that radiative forcing from human-added gree hous gases (o Gs) has increased by $27.5 \%$ between 1990 and 2009. In its analysis, inch os the atmosphere are responsible for $80 \%$ of this rise. It further tated that the contribution of radiative forcing by methane $\left(\mathrm{CH}_{4}\right)$ and chloroflut abons (CFCs) has been nearly constant or declining for the same period. USA, for instance with about $4.5 \%$ of the world's population, consumes an estimated $25 \%$ of the world's resources and produces an estimated $26 \%$ of global pollution (Govindaswamy, n.d.).

These increases in the atmospheric composition of our natural environment have had devastating effects. In Nigeria, for instance, the flooding pattern that occurred in recent times is a warning signal that needs urgent attention to forestall its reoccurrence. The National Emergency Management Agency (NEMA) has repeatedly given warnings that people of the southern parts of the country are likely to experience greater flood disaster this year (2013). This means that if left unchecked, there is the tendency for such changes to occur 
progressively. Although NEMA and other similar agencies prescribe temporary measures like relocation of the inhabitants of such perceived disaster-prone areas, a more permanent measure is needed. Such measures should be lasting and sustainable rather than palliative. It can only be achieved if the causes of climate change are made known to all so that there would be a collective effort towards finding a lasting solution.

\section{CAUSES OF CLIMATE CHANGE}

It has been widely accepted that the major causes of global warming are $\mathrm{rm}$ us human race and the effects on us will be severe. For instance, The Citizen ne paper of 2 June, 2013 (online version) reports that no fewer than 171 plant species vere ssified endangered and vulnerable; and that these plants are harvested from our fores hro gh commercial activities that cause rapid deforestation at about 400,000 tares $r$ ann. The disappearance of the affected species could disrupt the nation's gen tic ree wit resultant threat to our biodiversity. The same newspaper reported that ne gove of $y$ elta State, Nigeria needs over 200 billion naira to tackle ecological Bef or umans, ch ses in climate resulted entirely from natural sources such as changes eart orbit, enanges in solar activity, or volcanic eruptions. But since the industrial cra egan, ho $/$ activities have had an increasing effect on climate, particularly by ad ing billions of tonnes of heat-trapping gases to the atmosphere. The main GHGs directly scharged by humans include $\mathrm{CO}_{2}, \mathrm{CH}_{4}$, $\mathrm{N}_{2} \mathrm{O}$, and several others. Derek Markham (2009) thed the following as the causes of global warming:

1. Carbon dioxide emission from fossil utc ning power plants: Man's increasing addiction to electricity has led to establishme to of se cral coal burning power plants which release enormous amounts of carl lioxide to the atmosphere. The U.S. Environmental Protection Agency (EPA, 2010 noted lat $40 \%$ U.S. carbon dioxide emissions come from electricity production, and $\mathrm{un}$. utility industry.

2. Carbon dioxide e cion fron burning gasoline for transportation: With the increasing demand moc means of transportation and distribution of globally sourced goods, automob, es are increas in number yearly. In the U.S., for instance, the EPA (2010) notes that ab i $33 \%$ of the en irssions emanate from automobiles. For developing countries like Nigeria $h$ very $h \mathrm{~h}$ population figure, the demand for both new and used cars and consum goods eps Acreasing. This translates to increasing use of fossil fuels for tran orta $\mathrm{h}$ and $\mathrm{h}$ afacturing, often without sourcing for alternative energy resources and cer. yen wincreasing carbon dioxide concentration in the environment.

3. Mu ne emissions from animals, agriculture, and from Arctic seabed: When organic $\mathrm{m}-\mathrm{r}$ is broken down by bacteria under oxygen-deficient conditions (anaerobic decomposition) as in rice paddies, methane is produced. A similar process takes place in the intestines of herbivorous animals, and with the increase in livestock production, the levels of methane released into the atmosphere is increasing. Also, methane from methane clathrate (a compound containing large amounts of methane trapped in the crystal structure of ice) increases the rate of global warming significantly, as methane escapes from the Arctic seabed.

4. Rapid deforestation for agricultural, commercial and industrial purposes: Man's quest for urbanization, industrialization as well as production of food crops has led to increasing deforestation in the tropics. Forests remove and store carbon dioxide from the 
atmosphere. Deforestation releases large amounts of carbon, as well as reduces the amount of carbon capture on the planet.

5. Increase in usage of chemical fertilizers on croplands: In recent times, due to rapid population growth, especially in the underdeveloped nations, there is increasing demand for food and higher crop yields. This has led to more use of chemical fertilizers than animal manure. It has been established that nitrogen oxides have up to 300 times more heat-trapping capacity per unit of volume than carbon dioxide. Also the run-off of excess fertilizers creates 'dead zones' in our oceans. In addition to these effects, high nitrate levels in ground water due to over-fertilization calls for human health concern.

\section{EFFECTS OF CLIMATE CHANGE ON MAN AND HIS ENVIRQ ME}

1. Rise in sea levels globally: Scientists predict an increase in se2 ls yondv de due to the melting of two massive ice sheets in Antarctica and Green ${ }^{1}$ e cially o the East coast of the United States of America. However, many other tions inc ino Nigeria are already experiencing the effects of rising sea levels (and flo din the coasy, lands), which has displaced millions of people.

2. Massive crop failures: A recent research by Watch magazine (April 18, 2013) indicates that the worldwide will have to choose between moving th hungry due to climate change within 100 vears. Th

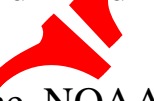

ne NOAA as re orted by the Climate is a $90 \%$ hance that 3 billion people families o milder climes and going change on water supply would be sever artages in water supply will affect food production, reduce sanitation, and hinder e no s. elopment and damage ecosystems. Climate change causes violent swings between oods and droughts.

3. Rapid and widespread ex nctio of spec $\%$ For a balance in the ecological system to

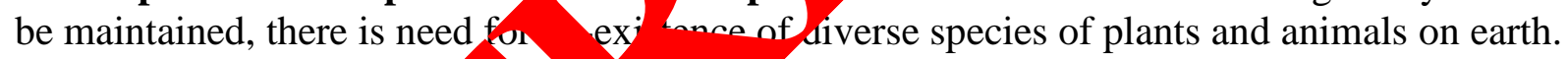
Climate change presents a grout th. to a vast number of plant and animal species inhabiting the earth. Rising tempe res could d/o widespread species loss, and lists of endangered species keep growin Thi $s$ attracted attention on many fronts.

4. Disappeara ace of coral $\%$ : Despite the immensity of oceans (about $71 \%$ of the earth's surfac with average depth of $4 \mathrm{~km}$ ), there are indications that it is approaching its tipping point. $r$ port o coral reefs (WWF, n.d.) says that in a worst scenario, coral populations will lapse y 2100 due to increased temperatures and ocean acidification. The bleag Ing corals 1 small but prolonged rise in sea water temperature is a severe danger fo ean cosystem, and many other species in the oceans that rely on coral reefs for their surviv

5. Moru "er storms: The severity of storms such as hurricanes and cyclones experienced in recent times across the globe is on the increase. Scientists are of the belief that global warming will significantly increase the intensity of the most extreme storms worldwide. This has been associated with rising ocean temperatures.

From the above analysis of the causes and effects of global climate change on man and his environment, it is very clear that individual and government intervention is needed to forestall this negative trend. Government's intervention, particularly in conservation efforts, is very important if the much desired sustainable development is to be achieved- through science education. 


\section{WHAT IS SUSTAINABLE DEVELOPMENT?}

The idea of sustainable development resulted from the 1987 report of the Brundtland Commission to the United Nations World Commission on Environment and Development. The objective is to provide all kinds of people with educational opportunities that enable them to acquire knowledge and values, as well as adopt the behaviour and lifestyles that are necessary to make the future worth living and to bring about positive social change. According to this report, sustainable development is the "development that meets the needs of the present without compromising the ability of future generations to meet their own-meds". It promotes the idea that social, environmental and economic progresses are ${ }_{1}$ attan within the limits of our earth's natural resources.

Sustainable development approaches everything in the world as bein connect through space, time and quality of life. In terms of the earth being conne ied throug ace, it implies that whatever environmental practices being carried out one untry so the capability to impact on another country. For instance, the air poll ion $\mathrm{g}$ emit $d$ here in Nigeria has the capability of affecting the quality of air in not $j$ st the ner ouring countries like Cameroun, Chad or Niger but across continents. In ter the earth connection to time, this could be demonstrated in how the choices the generations are either benefitting or suffering the present generation or ho own do could affect the future generations. To illustrate this, consider wh t environment o, r children and grand children will live in if we fell all the trees now with t replanting or if we embark on the use of chemicals to hunt for the aquatic creatures. The ult is ob/ious- many species will be extinct. For any development to be considemad sustaina ctore, it should seek to address the following issues:

- What is to be developed? All developm nt shou, consider first, the people in terms of child survival, life expectancy, equal pportunity, etc. It should also consider the economy (wealth creation, pr uctiv sectors, Onsumption), and the society (institutions, social capital, regions). Any de ort that is not geared towards improving these factors is not worth emba sing upo

- What is to be s sta $\mathbf{s}$ ? In tryi g to answer this question, we consider the effects of such developmenth natur arth, biodiversity, and ecosystems), life support (ecosystem services, resour es, and environ ht) and community (cultures, groups and places).

- For hon ong wil be sustained? Here we critically look at the span of such development. A the re alts of such development going to have immediate, future or everl otm ffects tre components listed above? Questions regarding the effects of such de opme t effort s ould also be addressed (U.S. National Research Council, 1999).

Tchieve sustainable development, therefore, we have to seek for ways of addressing our socia d/economic problems of the present without exhausting the earth's finite natural resources, , hich are expected to support the future generation live a kind of life that will not be of lower quality than ours. One major way of addressing the environmental problems created by man's activities is education, especially in science through the schools since the school is the most appropriate medium through which issues concerning the society can be related to the younger generation. This role rests heavily on science educators. 


\section{WHAT IS SCIENCE EDUCATION AND WHY DO WE NEED IT?}

The word science probably makes us think of thick textbook, white lab coat, laboratory instruments, microscopes, a naturalist in the rainforest, Einstein's equation written on whiteboard, the launch of space shuttle and etc. However, those pictures only reflect some aspect of science, but they do not provide the whole picture of science. So, what is science? Science can be said as part of everyday life, where it exists all around us. Science has many disciplines such as chemistry, physics, biology and engineering. To conclude what science is, let's see the diagram below;

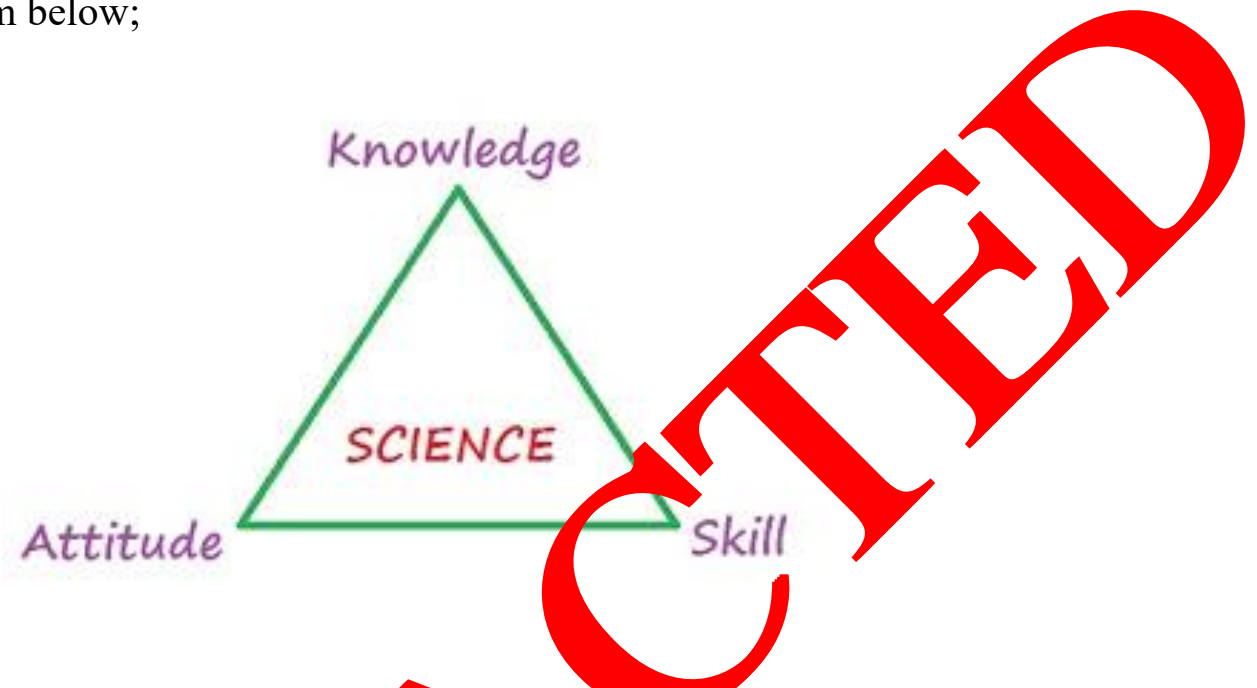

Science is composed of attitude, s and knownenge (ASK), each of which has different domains involved. For example, how involves cognitive domain and skill involves cognitive and psychomotor domains $T_{M}$ is is oecause science process skill involves critical thinking in attributing. H we use cognitive domain. In science, we also have manipulative skill that uses ps homo or doma . Lastly, attitude such as accuracy, involves affective domain. Each of th se for in the process of education.

Science education an be do d as a discipline or field of study concerned with the integration of science $a$ nt and pr with pedagogy in order to promote meaningful understanding and a lica of science among learners, or the study of science content and process with emr nawis on how th to promote their teaching and learning in order to achieve optimum bene its. (N vorgu, 20 J). Education for sustainable development, on the other hand, comprises un ects of environmental protection, the efficient utilisation of natural resources the in tenang of the ecosystem and responsible attitudes among members of socie a the bs community. Science education is thus an integral aspect for su nable developnent.

e to science education than simply learning about our theories and laws. It also inc s learning how to protect the environment. This is impressively demonstrated by the anti-lit Ing campaigns that are regularly implemented in many towns and cities in Nigeria, and throughout Europe. Such initiatives where citizens clean up towns and cities do not just have the effect of cleanliness. They encourage citizens to act in a responsible way and to appreciate the environment. Education generally influences behaviour but science education specifically makes people aware of which environmentally harmful acts are prohibited.

The Nigerian national policy on education (FRN, 2004) recognizes the place of the child's environment in the child's life and overall well being. Hence the child's learning is always designed in a way that it can enable him/her fit into his/her environment. At the pre- 
primary level, Education should among others (i) inculcate social norms, (ii) inculcate in the child the spirit of enquiry and creativity through exploration of nature, the environment, art, music and playing with toys, etc. (p.11). At the primary school level, education should also develop in the child the ability to adapt to their changing environment, among others (p.14). Similarly, the UN designated the period 2005 to 2014 as the decade of "Education for Sustainable Development". The objective is to integrate the concept of sustainable development in education process around the world. Science education is an integral aspect of this concept. Environmental problems such as climate change jeopardize our prosperity and our economic development and can best be handled by science educators.

For the child to understand that his environment changes and be able therefore, he should understand the components of the environment. Such kno and technology in today's world is overwhelming and therefore throughout the world has to gear itself to provide the required traini in sc tific s $1 \mathrm{~s}$ to meet this growing challenge. Undoubtedly the application of sci nce techno have transformed the world through dramatic advances in almost a fields ydin medicine, engineering, electronics, aeronautics etc. and in more recent thatic s in computer technology have revolutionised in particular the informatian nd co vunications sector.

The evidence of the correlation betwe n cience $y /$ technology and economic/industrial development is overwhelming. $/$ fact, many coun ries have transformed themselves from poor feudal type economies thro $h$ the incressing application of science and technology. In this regard, China and India are outstarding examples as they have grown to become economic and industriol power and in several ways compete effectively with developed countries. Had heen for science and technology, Europe would not have been able to rebuild in such a rela 1 hort time after most of the countries there were flattened during World War II (Pra ash, 2011). So it is not whether scientific and technological road is an option? onv $t$ is an nperative and has to be vigorously pursued, especially Nigeria, which, use of a mutiplicity of factors lags in scientific and technological developmen tha is oum roubling is that the number of students at the secondary and tertiary 1 als pursun cience has been decreasing, especially in physics and chemistry. Then the is o an attr dinal problem with respect to science where many students feel that cerce sub ts are too difficult and therefore shy away from it. Therefore it would seem that the issue has be tackled on two fronts - providing the incentives and motivation $f$ the $p$ yit of serence and changing the attitude of students. Achieving these tasks will not asy bec ise of the numerous difficulties and complexities involved but a good st to e oy school system to make them science friendly. This of course has beer reco ised by pros $\mathrm{nm}$ modress the issue. This indeed will always be a challenge in developing countn but perhaps one of the avenues that should be pursued to help alleviate this difficulty geking support from the private sector, particularly industries, which ultimately will benef $\lambda$ from scientifically qualified trained personnel coming out of the education system. However, another which should come under closer scrutiny is the science curriculum to determine whether its content and structure are towards meeting objectives and stimulating children's interest in science. This is a crucial area and should not be overlooked. 


\section{CONCLUSION AND RECOMMENDATIONS}

From the foregoing, it is imperative that science education should be given serious attention in school curricular considering the benefits derivable from it. For the child to be well informed about his environment, he has to interact with his environment, and by so doing, gain a first-hand and deeper knowledge and information about his environment. Such knowledge can only be impacted by those who have sound science background. It is therefore recommended here as follows:

A) Nations of the world should repackage their various schools curricular to emmhasize science education.

B) Sciences should be made compulsory at least up to senior secondar chool lev especially considering the challenges posed by climate change which many neop ontribu to ignorantly.

C) Science teacher education programmes should be given adequa attent in to is of funding so as to increase or enhance teachers' commitment to their with

D) Rather than spend scarce resources on controlling enviror nental du datic a resulting from climate change, such resources should be channeled on ts educath the pupils on proper environmental practices, through science educatio. Thi prevertive rather than palliative. In conclusion, the effects of climate change parr ave far- bing negative effects on man and his environment, if nothing urgent is do e to enlighten the masses of the dangers of certain activities we engage in as we purs industrialifation. This enlightenment campaigns cannot be effectively carried out using th ass medi only. The school is the best avenue for addressing this issue, especially through th of environmental education as a core subject in school curricular.

\section{References}

[1] Climate Watch (2013, vil Ouom emperature update. Retrieved from www.noaa.gov

[2] Environmental F tect. Agency 2010). Global Warming: Executive Summary. Retrieved fro inttp://yos te apa.gov/OAR/globalwarming.nsf.

[3] Federal $\mathrm{P}$ public fNigeria. (2004). National Policy on Education. Lagos: NERDC press. Govindas V. (n. ). Importance of Environmental Education for Sustainable Der petrie ed from www.ces.iisc.ernet.in

[41 Garkh m D. (20 9). Global Warming - effects and causes: a top 10 list. Retrieved from e.com

[5] Nati 1Besearch Council (1999). Our common journey: a transition toward sustain oility. Washington, DC: National Academy Press. Retrieved from http://www.sustainabledevelopmentinfo.com.

[6] National Research Council. (2010). America's climate choices. Retrieved from http://nas_sites.org.

[7] NOAA (2010). Annual greenhouse gas index. Retrieved from http://www.esrl.gov/gmd/aggi 
[8] Nworgu B. G. (2010). Research in science education in Nigeria: conceptual, methodological and analytical issues. Guest lecture delivered at the $2^{\text {nd }}$ national conference of the School of Sciences, Federal College of Education, Okene, August $10-13$.

[9] Prakash J. (2011). What is the importance of science education as a school subject? Retrieved from http://www.preservearticles.com DOI: 201105216961.

[10] The Citizen Newspaper (2013, June 21). Nigeria's endangered species. Online version retrieved from www.thecitizen.com/public-affairs.

[11] United Nations (1987). Brundtland Commission report of World Commissi on on Environment and Development. Retrieved from http://www.un.org/documents/ga/res/42/ares42-187.htm.

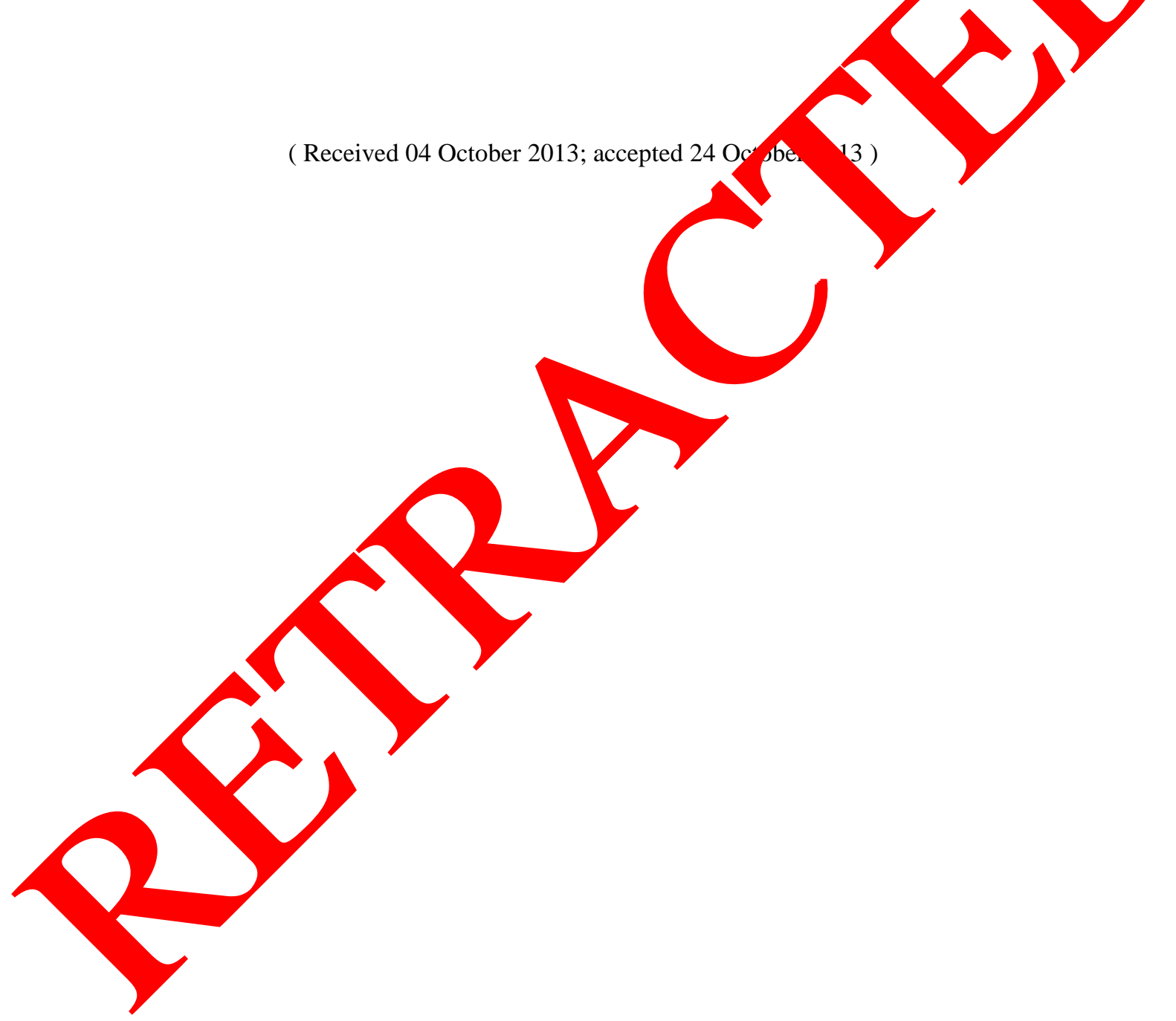

